\title{
Remediation and Counter-Hegemony of Gender Dichotomy in Indonesian Family: Multimodal Discourse Analysis of Two Kecap Advertisements
}

\author{
Justito Adiprasetio ${ }^{1}$ \\ Faculty of Communication Sciences, Universitas Padjadjaran, Indonesia
}

\author{
Annissa Winda Larasati ${ }^{2}$ \\ Cultural and Media Studies, Graduate School of Universitas Gadjah Mada, Indonesia
}

\begin{abstract}
Until now hegemonic gender dichotomy in Indonesia has worked in various spheres of human life, in various social roles, even in the smallest unit of social organizations: family. The dichotomy was caused by the ideology of "State Ibuism" which was disciplined during the New Order era between 1965 and 1998, where women would play the role of mothers as a subject of private work, serving various domestic needs of the family, while men play the right role conversely. Discipline works through various media formalized through the Marriage Act 1974, which explains the role of men and women in a married relationship and Panca Dharma Wanita principles, which lays the foundation of the ideal women. These ideals remained entrenched even after the New Order regime's fall. Kecap ABC advertisements attempt to counter the hegemony over gender dichotomy and patriarchal division of work roles. This article uses Kress and Van Leeuwen's multimodal discourse analysis to show how an attempt to counter ideologies was made to be remediated through the modalities contained in these advertisements. This research elaborates on how these advertisements represent women as superior in terms of dealing with exploitation that occurs in a family, and shows how the renegotiation of domestic work is possible. This research also elaborates how the male body as a mediator of masculinity is actively mediated through modalities such as speech, gestures and moving images, by showing how men can also do domestic work.
\end{abstract}

Keywords: Gender Dichotomy, Masculinity, Remediation, Counter-Hegemony

Introduction

Globally, in the past few decades, gender representation in popular media, especially in advertisements, has undergone changes in a more positive direction (Grau \& Zotos, 2016). In America for example, there is an increasing number of representation of women in fields which in the past were considered to be owned by men and conversely, while men's representation tended to be softer and more egalitarian (Hatzithomas, Boutsouki \& Ziamou, 2016). Changes and negotiations in various gender roles also appear in various advertisements in the past decade. The representation of men in advertising today is far more realistic

\footnotetext{
${ }^{1}$ Corresponding e-mail: justitoadiprasetio@gmail.com
}

${ }^{2}$ Corresponding e-mail: anisawindalarasati@gmail.com 
and it does not emphasize masculinity as much as before, even offering a new identity: metrosexual, which are men who enjoys traditionally feminine activities like shopping or fashion (Harrison, 2008; Fowler \& Thomas, 2013). Even though it works completely evenly, Yann Verhellen, Nathalie Dens and Patrick de Pelsmacker's study (2016) shows that television advertisements in Belgium are still clinging to stereotypes in the sense that women are often described as housewives or men's sex objects although there has been a change in gender roles at the practical level in Belgian society itself. Meanwhile, advertisements in South Korea predominantly represent women as dominant actors in the domestic sector (Kim \& Lowry, 2005). This shows that the discourse in the media is not always directly proportional to the discourse in everyday cultural practices.

In the Indonesian context, various contradictions in terms of discourse and gender representation also occur. On the one hand, there are still advertisements for male body care products that feature women as objects of desire, leisure, and sex (Hermawan \& Hamzah, 2017), or advertisements showing that women are limited to various domestic roles as wives or housewives that are responsible for childcare, family health care, or household responsibilities (Siswati, 2014). But on the other hand, there are various Indonesian advertisements that try to reconstruct gender and gender roles in daily practice by highlighting equality and more equitable division of labor between men and women (Pratiwi \& Wiyanti, 2017). For instance, two Kecap $A B C$ advertisements which are under the auspices of jargon: Akademi Suami Sejati (The Real Husband Academy) try to offer alternative narratives on gender dichotomy.

ABC Central Food was established in 1975 in Jakarta, Indonesia (Heinz, 2019). Initially selling Kecap ABC soy sauces with sweet and salty variants, they expanded to syrup, ketchup, and chili sauces later on. In the 1980s $A B C$ 's products began to dominate the Indonesian market. Along with their market domination comes their advertising materials across various media platforms.

In 2018 ABC Central Food launched a series of television advertising consisting of 'Suami Sejati Mau Masak, Terima Kasih Kecap ABC' (Real Husband Wants to Cook, Thank You Kecap ABC) and 'Kecap ABC Bantu Suami Jadi 
Pasangan yang Setara' (Kecap ABC Helps Husbands Become an Equivalent Partner), which aired on television at prime time (Heinz ABC, 2018a; 2018b). Both advertisements were also uploaded on Youtube, where each gets 3 million viewers and 5.2 million viewers respectively by the end of November 2018. The ABC Advertisement Series itself offers a challenge to the traditional concept of masculinity and femininity, where $A B C$ 's advertisements represent men who can cook as a 'real men', and women who are also working. $A B C$ 's advertisements become part of a counter-hegemony that attempts to challenge the gender dichotomy and the division of roles in gender categories.

This study explores how Kecap ABS's advertisement series attempt to offer alternative discourses related to traditional gender roles. Firstly, this paper examines how the traditional gender roles in Indonesia are formed. Afterwards, the paper applies Gunther Kress and Theo Van Leeuwen's (2001) multi-modal discourse analysis method to understand how tideological aspects are represented in Kecap $A B C$ 's advertisements and how the advertisements attempted to challenge traditional gender norms.

\section{Literature Review}

The concept of masculinity and femininity has been challenged for decades. Historically, masculinity was defined with expressions of dominance, independence, self-confidence, strong determination, and ambition (Kimmel \& Tissier-Desbordes, 1999). However, this perception has changed a lot. Since the beginning of the 1980s, there has been a shift in how people define masculinity and this phenomenon can be observed in popular media. For instance, in the 1970s the popular image of a masculine figure was the 'Marlboro-Man' with their muscular body, strength, and their ability to use mechanical equipment (Brandt, 1995). In the early 1990 s masculinity starts to be referred to the 'BusinessMan' figures: smart, shining and takes care of himself (Brandt, 1995). This shifting image of masculinity continues in the 2000s. As Claire Harrison (2008) noted, companies started to use men as the main actors in their makeup advertisements, which are products traditionally marketed to women. For instance, Korean cosmetics brand Etude and Tonymoly attempted to offer a new form of masculinity where men can use cosmetic products and take care of themselves (Fatimah, Priyatna \& Adji, 
2017). This imagery continues well into the 2010 where men are doing domestic works, such as washing, cooking, and preparing breakfast in advertisements (Pratiwi \& Wiyanti, 2017).

In the Indonesian context, efforts to represent gender in an egalitarian manner and to dilute the strong dichotomy of gender roles face challenges that are historically and culturally different when compared to Western countries. Patriarchal discourse has settled in various aspects, even in the deepest joints of the country. The division of roles between men and women in an Indonesian family is outlined through the 1974 Marriage Law, Article 34. The law obliged husbands to protect their wives and provide everything they need to live according to their abilities, and for the wife to household affairs as well as possible. The law also stipulates that if either the husband or wife neglected their obligations, they can file a claim to the court.

The regulation passed by the New Order authoritarian regime in 1974 was an adaptation of the Burgerlijk Wetboek (Civil Code), which was effective in the Dutch colonial period. The Marriage Law provides a clear definition of the role of husbands and wives when they are married, that men have the responsibility to be the protector of the family-a public role, and women are regulators of domestic affairs. Suharto who was the dictatorial President during the New Order regime projected himself as a super-patriarch father of Indonesia, the development family he wanted (Wieringa, 1999). Niels Mulder (2001) concluded that family discourse was a New Order power strategy to reproduce compliance.

In the historical context, the structured discourse of the domestication of women's roles does not stand alone. The discourse is embodied in what Julia Suryakusuma (2011) referred to as "State Ibuism" or "State Motherism", in which the roles and duties of the Mother are disciplined and functioned as instruments of ideological discipline. This ideology continues to become a dominant discourse in various policies today. The idea of State Motherism itself has taken root long before the enactment of the 1974 Marriage Law as the domestication of women began to be carried out massively in Indonesia in the 1970s. During the 1970s the Indonesian government began to foster the Family Welfare Development (PKK) program 
and the founded the Dharma Wanitaan association civil servant wives-in August 1974. The organization holds a principle, namely Panca Dharma Wanita, which states that:

1. Woman as the husband's loyal companion;

2. Woman as a homemaker;

3. Woman as a successor to the generation and an educator to the child;

4. Woman as an additional breadwinner; and

5. Woman as a citizen and a member of the community (Wafiroh, 2017).

As reflected in its principles, Dharma Wanita aims to produce conformity and obedience where various practices and women's imageries are placed in relations to women as members of the organization. This ultimately means that the practices and imageries of women were under the purview of the state as the Dharma Wanita organization itself was strictly controlled by the state.

During the New Order era, the ideology that dominated the role of women is not only worked in the structural context of the state, but also through popular culture. One of them is through television series, such as Keluarga Rahmat (The Rahmat
Family), which aired in the mid-1980s and became the mediator of "familism" ideology. Keluarga Rahmat is a model of the "ideal" New Order society. The show projected moral values that the government expect its citizens to embed into their family lives. Instead of an entertainment, this makes Keluarga Rahmat what Philip Kitley calls a "tedious moral lecture" (2000).

Although the repressive New Order order collapsed in 1998, it turned out that the formalized formal structure did not run aground by itself. For instance the 1974 Marriage Law with various elements that explicitly dictate the responsibilities of husbands and wives as well as Panca Dharma Wanita. Ratna Noviano (2011) notes that the law and the Dharma Wanita's principles engender the New Order regime's perception of tradition, which largely refers to Javanese gender role ideals. Noviani also noted that in the post-New Order era advertisements still reflect women with similar Javanese ideals regarding gender roles, especially as housewives.

The process of breaking down the walls of the role dichotomy between men and women could be done through formal and structural ways so that they can change existing regulations, not 
only at the organizational level such as Dharma Wanita, but also the state level. However, the way to get there certainly requires massive encouragement from the community. Thus various grassroots strategies are needed. Efforts are not only to organize resistance but should also begin with the socialization of gender equality where men can play a role in the domestic sector and women can play a role in the public sector depending on their abilities and choices.

The strategy that can be done is to use various popular culture channels so that the messages of gender equality can passed on directly into the society. However, there is another challenge that must be faced, that is the grip of capitalism, which tends to commodify whatever is in front of it. Recent studies of advertising in Indonesia, for example, show that women often become commodities that are highlighted by their sexuality (Fernandez, 2011; Framanik, 2012; Fitriana, 2014; Noor and Wahyuningratna, 2017), as well as traditional male masculinity (Winata, 2012; Prameswari, 2014). In this dimension, we can see that what is found in Kecap ABC's advertisement series is a significant attempt to bend the traditional gender norm. As a part of the industry, Kecap ABC tries to offer an alternative narrative about how men and women are portrayed in the scope of modern family living.

Kecap ABC tries to remediate the gender dichotomy found in the family by presenting alternative narratives relating to gender roles through their advertisements. The concept of remediation begins with mediation, namely the process of transforming reality in everyday life into a media reality (Burton, 2002). Remediation as a practice focuses on examining the many ways that semiotic performances are re-represented across modes (Prior, Hengst, Roozen \& Shipka, 2006). This involves the movement of meaning from one text to another, from one discourse to another, and from one event to another (Silverstone, 1999). Remediation illustrates the inseparability of mediation and reality by reforming, reusing, refashioning, and repurposing mediated reality (Bolter $\&$ Grusin, 1999). In this case, Kecap ABC's advertisements try to remediate the traditional gender dichotomy through alternative narratives related to gender roles. Their narrative is disseminated in the form of videos that combine audio, visual and website aspects at once and. 
By airing their advertisement online and in television the company attempts to disseminate their message to the mainstream audience

To assess how ideological aspects are represented in advertisements Kress and Van Leeuwen devised a multi-modal discourse analysis method (2001). They posit that it is difficult to separate the modes contained in the advertisement without taking into account the relationships between narration, speech, space dimensions, gestures and various modality features in the form of a combination of visuality and audio. Kress (2009) defined this modality as socially shaped through the process of meaning making.

Arguing that Kress and Van Leeuwen (2001) have failed to give enough attention to linguistics and intertextuality in their method, Norman Fairclough devised instrumental analysis of the text (1992). In this method, firstly, one has to examine 'interactional control,' which is the relationship between the speakers. This includes the question of who determines the conversation agenda. Secondly, the 'ethos', of the text also warrants one's attention. The 'ethos' is the understanding of how identity is built through language and aspects of the body. Aside of 'interactional control' and 'ethos,' Fairclough also posits that the analysis of 'metaphor,' 'words,' and 'grammar' would also provide a detailed elaboration of the textual elements contained in advertising. Aside of analyzing the language used in the advertisement, Fairclough's method also takes into account intertextuality, which is how the advertisement reflects configurations of conventionalized practices available to the producers and audiences in particular social circumstances. Both Kress and Van Leeuwen (2001) and Fairclough's (1992) frameworks will be applied to analyze how traditional gender roles are challenged in Kecap ABC's advertisements.

\section{Discussion}

Suami Sejati Mau Masak, Terima Kasih Kecap ABC (Real Husband Wants to Cook, Thank you Kecap ABC)

This advertisement lasts for 46 seconds and are divided into three parts: firstly, the initial scene where each character-Father, Mother and Child-are separated between the dimensions of space modality. Secondly, the scene where Dad's character enters 
the kitchen, the stage that is previously held by the Mother. Third, the scene where the three characters sits around the dining table and eats. Discussions regarding this advertisement dimensions will be divided based on these three scenes.

\section{Part 1}

Father: Ahhh I'm tired (loosening the tie while putting a briefcase and sitting on the sofa)

(Mother is in the kitchen putting Kecap $A B C$ on the counter, preparing to cook)

Father: Who is that? (asking his daughter who is she drawing on the floor)

Child: This is the 'Super Mother.' Father: What is Super Mother's strength?

Children: A lot. She gets up early, works, cooks.

Father: What about me?

Child: You only work. Mother is still strong enough to cook even after she worked. (pointing towards the kitchen)

(Father looks at the kitchen then towards the child)

There are three characters in the advertisement: the Father, the Mother and the Child. All three characters are represented visually in one house. Although it seems that the three of them were in the same room, the marking elements that became the modalities of the dimensions of discourse in the room separated the room into three different

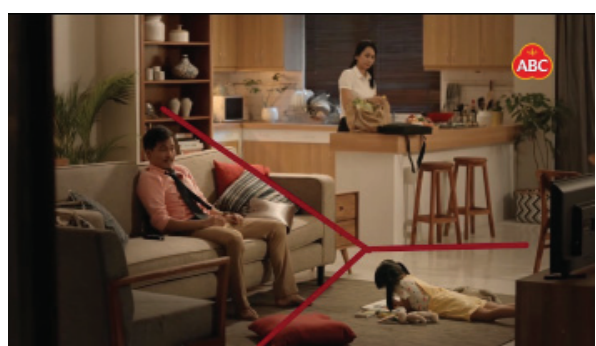

Figure 1. The opening scene of the ad that presents Father, Mother, and Child (Child) in one house but three different space modalities. (Author's compilation)

stages. The father initially stood, but then threw his bag and body onto the sofa. He effectively occupies a space that represents a place for relaxing, a place to rest, a place to spend time watching the television. The Mother stood in the kitchen, which represents the domestic workspace where women traditionally prepares food, cooks, and washes the dishes. Meanwhile, the Child lies on her stomach and draws on the carpet. This space represents children's playground and learning. The dimensions of discourse in the spatial form reveals the initial identity or ethos of each subjects in the scene.

This part of the advertisement remediates the concept of the house that is usually separated by borders to locate parts of the house such as the living room, kitchen, bedroom, and others, as it chooses to portray a kind of house with an open space. This allows the audience 
to see the kitchen and the living room in just one picture. Furthermore, this scene also uses an angle that helps the audiences to see the whole activities happening in the house from one point of view. This kind of remediation would let us attain what Jay David Bolter and Richard Grusin (2000) calls 'immediacy' or 'transparent immediacy,' which is defined as a style of visual representation whose goal is to make the viewer forget the presence of the medium (canvas, photographic film, cinema, and so on) and believe that they are in the presence of the objects of representation. The adoption of this cinematography style in the advertisement brings the activities and the ambience in the house closer to the audiences.

The dialogue in the advertisement starts with the Father complaining that he is tired; loosening his tie, putting his bag down and sits on the sofa. The gesture is a marker reveals an intertextual chain that implies that the Father has worked hard in the office. The scene was followed by him asking the Child who was lying down on the floor about the person she is drawing. Based on these questions we see interactional control at the beginning of the conversation held by Father's figure.

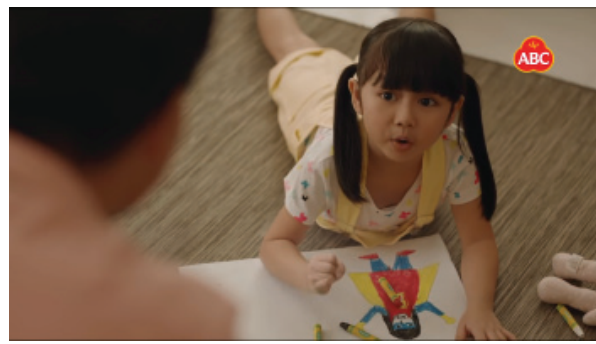

Figure 2. Child explains the picture to Father. (Author's compilation)

The Child's reply, "Super Mother," has intertextual relations with superhero characters in the popular culture, such as in comics and films. This directly refers more specifically to the "Superman" franchise characters, "Wonder Woman", and "Robin," as the three-color representation on the costume depicted in the advertisement strengthens the referential relation: red, yellow, blue. These colors derectly mirrorred the Superman franchise's superheroes. Other markers such as eye masks, symbols on the chest, and wings strengthen the relationship to superheroes who have super powers. Besides, the Child's choice to draw the character of the Mother is also a part of remediation where the concept of a strong woman, which represented by the superhero figure, is being refashioned by the child. As visible from her drawing, the Super Mother has a cloak which dangles from her shoulders. 
This mirrors superhero characters from Western traditions, but subverts it in a way that only male superheroes wears cloaks. For instance, male superheroes such as Superman, Batman, and Thor wears cloaks while famous female superheroes rarely wear cloaks. This part of remediation, again, leads us to immediacy or transparent immediacy where as viewers we could understand in a glance, even without a close-up angle, that the character drawn by the child is her mom, represented as a female superhero.

The dialogue continues with the Dad's question, "What is Super Mother's power?" And Child's answer is refers to the routine daily activities carried out by the Mother's character. She answered the Father in a way that the Mother's routine foreshadows super strength, and that the Mother's character is equal to other superheroes who are usually idolized by children. The Mother is represented as a figure who is loved by the Child.

The Father then asked the Child about her percerption of him. The Child answered quickly, "You only work. Mother is still strong enough to cook even after working," as she pointed towards the kitchen. The Father's expression changed as he heard the Child's answer: an expression of disappointment knowing that his position was not on par with the Mother, not only in Child's mind, but also as he reflected upon what happened so far. The representation of the Father's glum expression and tense gesture shows that the Father's character is reflecting on the unfairness of the division of labor in the household between the Father and the Mother.

\section{Part 2}

Father: (to Mother) Sorry, I never helped. If you can work, I can cook too.

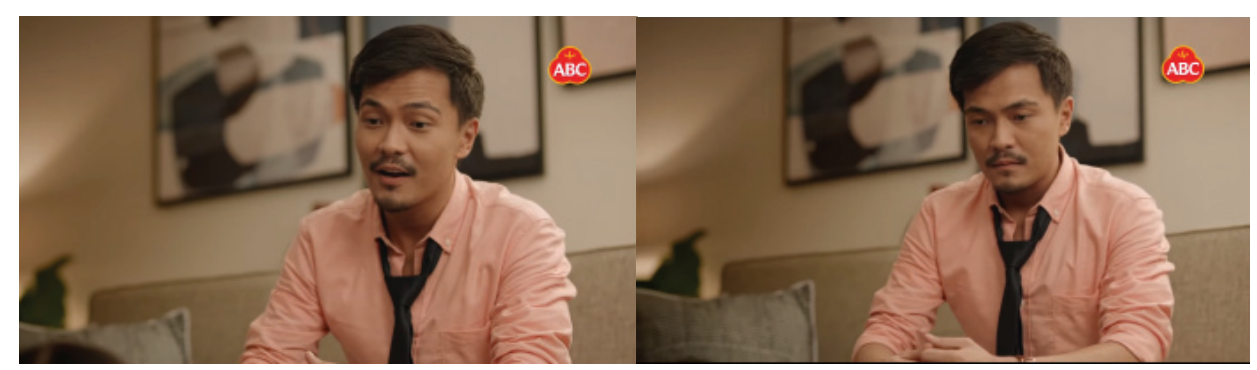

Figure 3. Father's scene whose expression changed after he heard the Child's answer. (Author's compilation) 
(Mother smiles, Father takes the spatula held by the Mother and starts cooking)

Mother: Want to help? This can help (while offering Kecap ABC to Father) Narrator (female): Kecap ABC, made of the first-pressed selected soybean. Make dishes more flavorful, [and] easier for anyone who cooks. ABC soy sauce, helps a real husband cook better.

The Father left the couch he had previously occupied, headed for the place which was previously only occupied by the Mother: the kitchen. The Father took the spatula which was held by the Mother. The Father said "if you can work, I should also be able to cook", the Father's statement showed that there should be equality and fair distribution of work in terms of roles in relations of husband and wife in the household.

The Mother, which did not speak before said "Want to help? This can help." the initial question contained a problem because the choice of the word "help" meant that the main role of cooking was in the hands of the Mother. The main role of domestic work in the kitchen is carried out by women, and the role of men is only "helping". The gender dichotomy is still portrayed in this dialogue, and ironically the speech is conveyed by a female character.
Despite a slight reflection of the traditional gender role, we can explore further that there is a remediation of male masculine identity in the advertisement. The husband's figure is represented as someone who is not only able to cook, but is also sensitive to his child's speech, which allowed him to evaluate himself.

\section{Part 3 \\ (Mother and Child sit at the dining table, Father comes to bring dishes to the dining table) \\ (Child eats Father's food, Mother strokes Father's cheeks as she smiles) (Child's picture now displays 'Super Mother', the Child and 'Super Father') (Child, Father, and Mother enjoy eating together at the dinner table) Narrator (female): Helps a real husband cook better}

The advertisement then continued with the image of chicken drumsticks being sauteed with soy sauce as the narrator talks about Kecap ABC. The closing of the advertisement then showed an image of the Father serving food and standing between the Mother and the Child who sat in the dining chair. As the Child ate the chicken, and the Father looked at the Mother. The Mother then held the Father's chin. The three of them were displayed with happy expressions, specifically as the 
advertisement implied that the Mother thanked the Father who helped her cook.

After the scene, there is a shot of the Child's drawing that has been updated amongst the food served on the dining table: 3 superhero characters each wearing a red uniform. "Super Mother" and "Super Father" who wear the same uniform, masked, winged, and both also held spatulas. The difference is that "Super Mother" helds objects that resembles laptop computers. The Child is represented slightly different, with the same color combination but with different color placement, and Child's clothes does not have wings. There are three heart markers that represent the love between the three superhero characters depicted by Child on the drawing paper.

The advertisement scene then closed with an image of Kecap ABC's plastic bottle packaging, with the background of the three characters mingling, laughing and eating the dishes on the table. The scene was closed with an animated slogan "Perasan pertama lebih kaya rasa" (The first press has a richer taste), accompanied by a female narrator's speech, which says "Helps a real husband cook better." This sentence refers to ABC's soy sauce, which will help husbands cook better. The narrator's speech is anachronic in this advertisement since there is no representation of Kecap ABC's ability in improving the Father character's cooking skills since the initial scene until the advertisement's closing scene.

The fashion modalities contained in this advertisement can also be further elaborated. The figure of a father who wears a pastel colored shirt and does not use colors that are historically considered masculine such as black, red or white, which indicates the existence of a sign game. Masculinity is not

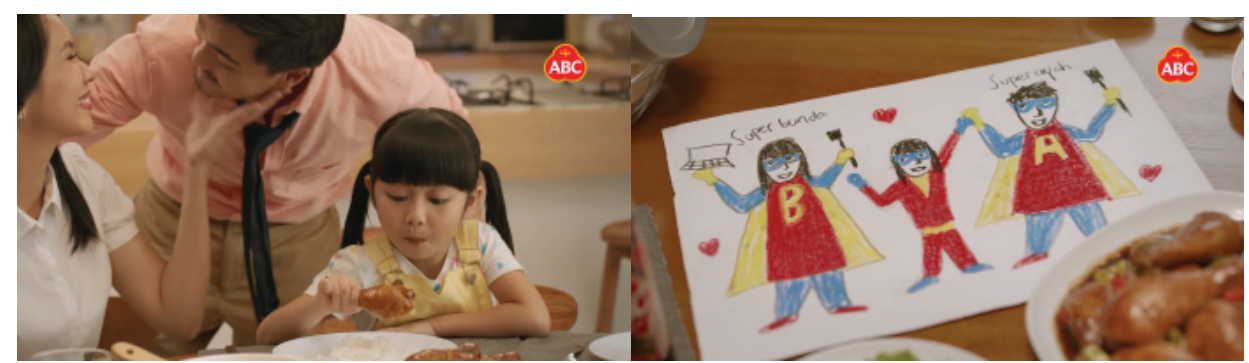

Figure 4. The closing scene, the Father serves food at the dinner table along with a picture of the Child next to the food. (Author's compilation) 
represented by strong colors, but it was negotiated with the use of pastel colors, which usually represent femininity. On the other hand, Mother uses white buttoned shirt, a neutral color that is usually worn by middle-class working men. This represents a metaphor of a "white-collar worker".

This part of the advertisement also shows how the Father as a male figure dressed as a mediation of masculinity is actively mediated in another medium. Since the goal of remediation is to refashion or reform the earlier version of the medium, we consider the ways in which this advertisement attempt to refashion and reclaim masculinity, specifically to challenge hypermasculinity which is often showed in Indonesian television advertisement. The character of the Father who wears a pastel-colored shirt and also has a sensitive feeling when he heard his Child challenges the mainstream hypermasculine image.

The same also applies to the character of the Mother who uses a white shirt, a rather neutral color for a woman in an advertisement, especially in advertisements of kitchen-related products where a woman is usually being highlighted. The female dressed body as a mediation of femininity is actively mediated in another medium by the neutral choice of color and the passivity of the Mother's character because this advertisement aims to refashion and reclaim gender dichotomy in Indonesian family: that the job to cook is not only for women, but also men. In brief, this advertisement challenges the patriarchal concept in family relation by showing the viewers how gender is not defined through the kind of roles people play within a family.

Kecap ABC Bantu Suami Jadi Pasangan yang Setara (Kecap ABC Helps Husbands Become Equivalent Couples)

This 1 minute 17 second advertisement is divided into two parts indicated by visuality, audio, gestures, and tone speech by the main figure of Andrie Jhony. The first scene (00.01-00.55) brings melancholy and nostalgic nuances characterized by slow image changes, piano background sounds with slow minor tones, and intimate gesture shoots, whereas the second scene (0.56-1.17) brings a more optimistic nuance that is characterized by a rapid transition of frames, vibrant piano beat along with cooking sounds, active gestures from the subject in 
the advertisement, and more dynamic camera panning than the previous scene.

\section{Part 1}

(Statistics on divorce cases in Indonesia in 2017, which is based on data from the Directorate General of the Religious Affairs of the Supreme Court)

(Caption) "ABC soy sauce wants to help reduce this number."

(Fingers with ring mark on his ring finger) Andrie Jhony: We divorced a year ago and it was my fault. I rarely help her. (Man holding both hands)

(Birds whistle in a cage exposed to the morning sun)

(Condition of a messy kitchen with dirty kitchen utensils)

Andrie Jhony: Even though she did everything [...]

(Dirty frying pan still on the stove, showing used cooking)

Andrie Jhony: [...] cooking, caring for the children (child photo in frame)

Andrie Jhony: Me?

(Male, sitting on the couch with a name and status statement; Andrie Jhony, divorced man)

Andrie Jhony: (sighs)

(Andrie Jhony turns his head to a window that is wet with raindrops, at night)

Andrie Jhony: I just leave for work early in the morning and goes back home at night (zoom in close to Andrie Jhony's eye shot)

(Andrie Jhony washed the glass in the kitchen sink, zooming in on the part of the hand that was washing)

Andrie Jhony: I should have done more.

(Andrie Jhony's hand cuts some spices) Andrie Jhony: Doesn't marriage mean being an equal partner in life, or in the kitchen?
(Picture of Andrie Jhony's wedding photo \& his ex-wife)

(Andrie Jhony cuts something on a cutting board in the kitchen, the picture is taken from the back side of Andrie Jhony)

(Andrie Jhony sits on the sofa)

Andrie Jhony: Maybe it's too late for me. (zoom in, medium close up shot Andrie Jhony)

Andrie Jhony: But not for you. (draws breath) Be a real husband who wants to help [...]

The first part of this advertisement was opened with the visuality of brick walls, with the dominat color of gray and minimal light and the data on divorce cases in Indonesia in 2017. There iss a small statement at the bottom which indicated that the data came from the Directorate General of Religious Affairs at the Supreme Court. There is a visual transition where the data is replaced by the phrase "Kecap ABC wants to help reduce this number" with the same typographic characters. Since the beginning this advertisement has shown explicitly and verbally that the big theme of this advertisement relates to divorceme.

The subject is implied to have had a dialogue with another figure in front of him, even though it is not visible, and the conversation can not be heard. The figure of Andrie Jhony whose identity 


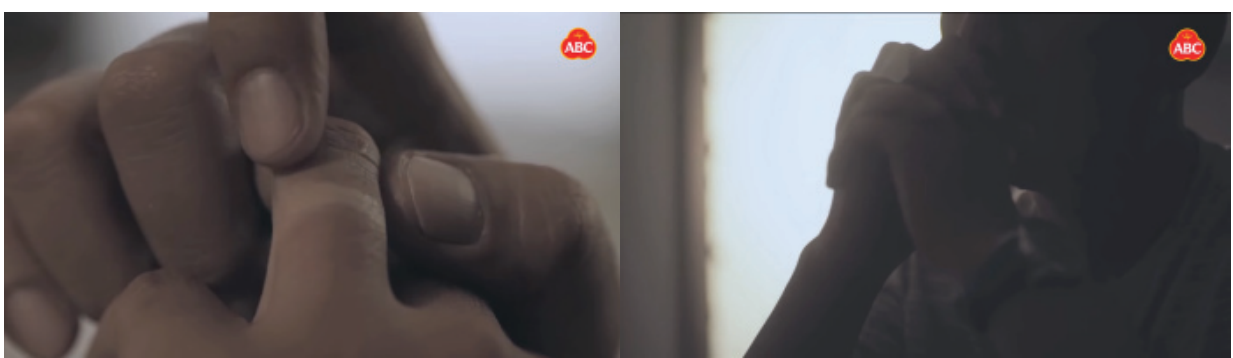

Figure 5. Andrie Jhony's close up hand and gesture scene (Author's compilation).

will then be displayed explicitly in the middle of the video is mostly displayed with the activity of sitting on the couch facing his interviewer and who listens to his statement.

The theme was then highlighted with visuality and continued speech after the transition, "We divorced a year ago and it was my fault. I rarely help her," which is accompanied by a visuality of the ring finger that has a circular ring mark, implying that the subject was married. Recognition in the utterance "it was my fault" is reinforced by his hand-holding gesture, which resembles someone with regret of their sin or someone who is praying to God.

In this part of the advertisement various elements are presented, such as darker visual imagery, more close up angles, dramatic music, and the narration was delivered by the actor himself. The combination of these elements or mediations-the representation of the object-also shows how remediation works as it tries to reform the concept of regret through a masculine character, which is the main actor in this advertisement. This is what Bolter and Grusin (2000) called hypermediacy as another effect of remediation besides immediacy, which is a style of visual representation whose goal is to remind the viewer of the medium. Digital hypermedia seeks the real by multiplying mediation so as to create a feeling of fullness, a satiety of experience, which can be taken as reality (Bolter \& Grusin, 2000). As a result, the start of the advertisement feels more real as the viewers could feel what the main actor feels by the combination of some elements or meditations.

The scene continues with the visuality of birds whistling in a cage, together with the actor saying "I rarely help her." Textual relations between speech and visuality builds structures 


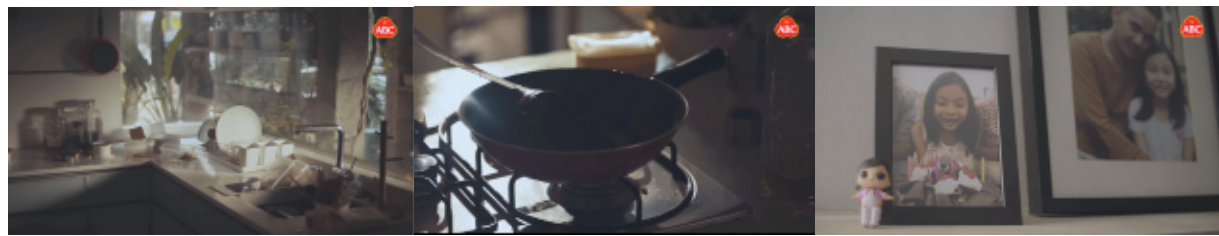

Figure 6. The scene that represents the condition of Andrie Jhony's house; the kitchen and photographs in the family room (Author's compilation).

of meaning of 'rarely help,' implying that it caused by the activity of caring for pet birds as a marker of other hobby activities.

The scene continues with the visuality of the kitchen where dirty dishes were piled up. The dishes represent domestic work, such as cleaning; the cooking pan and baking pan on the stove represents cooking; and two photos, each of which shows a child, represents child nurturing. The first photo, a child facing a birthday cake, is flanked by two non-visible figures, and a second photo of the actor who is hugging the child on the first picture who is smiling. Andrie Jhony continued his unfinished previous speech, "even though she did everything, working, cooking, taking care of the children". The three imageries and speeches are representations of domestic work carried out by Andrie Jhony's ex-wife where he did not help her.

The choice of the word "help" in the sentence "I rarely help her" indirectly presupposes the figure of wives and women as the main actors of domestic work. Men or husbands with various regrets found in Andrie Jhony's figure felt guilt for not helping. As in the first advertisement, there is an idealization of domestic work that must be done by women or a wife.

The scene continues with a visual transition to the male figure sitting on the sofa with a description of the name "Andrie Jhony" and the status of "Divorced Man". Jhony's figure then asked "me?" as if the scene is a part of a conversation, even though the utterance and the interviewer are not explicitly displayed on the visual and audio representation.

Jhony sighed and leaned his head to the window that was wet with splashes of rain at night. Melancholy nuances and regrets are built by there gesture markers, which is then reinforced by the visibility of zoom and close up shots of Andrie Jhony's eyes. The saying "I just leave for work early in the morning 


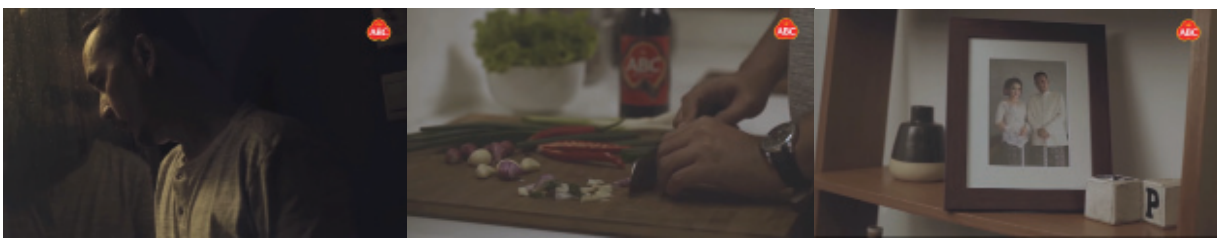

Figure 7. Regret and Andros Jhony's retrospect scene for his marriage. (Autho's compilation)

and com home at night " fulfilled the scene. This scene represents Andrie Jhony who regrets that he only worked every day without thinking about how the domestic life of the household is managed.

Jhony said "I should have done more" with the visuality that he was washing the glass in the sink, cutting vegetables as food ingredients and continued with him saying "Doesn't marriage mean being equal partners, in life, or in the kitchen?" accompanied by the visuality of Andrie's wedding photo frame of himself and his ex-wife and the visuality of Andrie Jhony cutting something on the cutting board in the kitchen, the picture was taken from the back side. This part of visuality is still an elaboration of the expression of Andrie Jhony's regret about marriage, which he felt could have been avoided if he did a lot of things and helped domestic work done by his wife.

Visuality transitioned with Andrie Jhony sitting on the couch and said "maybe it's too late for me" with the affirmation of the perspective of the camera zooming in, a medium close up shot on Andrie Jhony. The first part of this melancholy is closed with utterances "but not for you. (exhaling) Be a real husband who wants to help."

\section{Part 2}

(Close up of cooking pan shot which is full of food ingredients for cooking) Andrie Jhony: [...] those who want to cook

(Close up shot of Andrie Jhony's hand cooking and stirring a cooking pan with a spatula, pouring Kecap ABC into a cooking pan which contains rice and other ingredients)

(Andrie Jhony cooked and stirred dishes with a spatula, medium shot) (Andrie Jhony poured fried rice from a cooking pan on a plate, closed up shot of the hand)

(Picture frame of Andrie Jhony with his ex-wife and child blowing out birthday candles)

(Caption) Kecap ABC wants to help husbands become partners that are the equivalent of the First Press Has Richer Taste Recipes

(Andrie Jhony sat at the dining table while eating cooked dishes, zooming out shot)

(Close up shot of Andrie Jhony eating food at the dining table) 


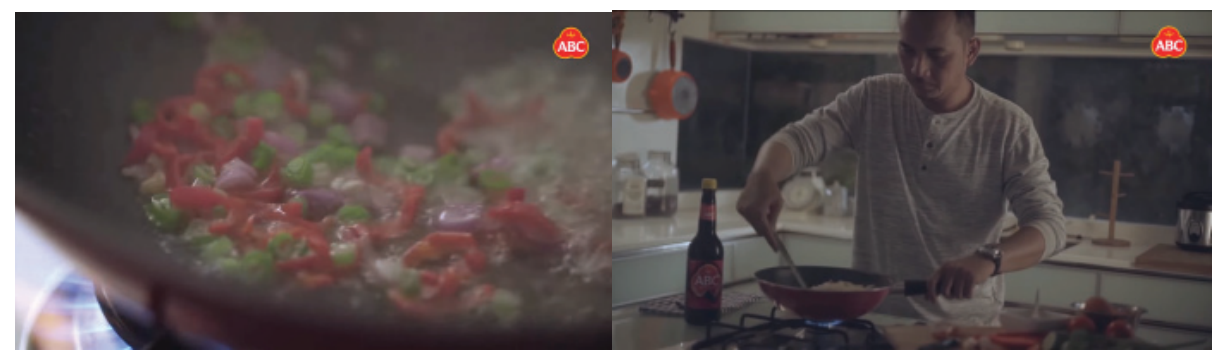

Figure 8. Andrie Jhony's cooking scene. (Author's compilation)

Andrie Jhony: Find out more in Kecap ABS's The Real Husband Academy

(tab that contains ads www. akademisuamisejati.com)

If in the first two parts of the advertisement the piano's tempo was slow, but it changes in the 00.56th seconds where the piano's tempo increased with the stirring sound of the food. Visuality shows close up of cooking pan's shot full of food ingredients for cooking. There is a continuation of the words in the previous part that are not finished, "[...] those who want to cook," which refers to a real husband who cooks.

The visual representation continues with a close up shot of Andrie Jhony's hand who was cooking and stirring a cooking pan with a spatula, pouring Kecap $A B C$ into the cooking pan onto rice and other ingredients and Andrie Jhony stirring the dish with a spatula on a medium shot. Andrie Jhony poured fried rice from the cooking pan on a plate, close up shot of the hand.

In this part of the advertisement, the male body as a mediation of masculinity is actively mediated in another medium, which is the advertisement itself. The way a man refashion and reclaim the masculinity through this advertisement is showed by the activities of the main actor, which is regretting, lamenting, washing dishes, and cooking as the activities that are rarely shown in Indonesian advertisements on the television. This part of the advertisement is reforming the concept of masculinity and gender roles in Indonesian family life by showing that a man or (ex) husband can do domestic work just like a woman or a wife. This advertisement also rejects the concept of patriarchal concept in family relations.

The second part closes with a photo frame with Andrie Jhony with his ex-wife and child who was blowing out birthday candles. There is a visual representation 
of the phrase "Kecap ABC wants to help husbands become equal partners with First Press Has Richer Taste Recipes." On the background Andrie Jhony is eating his own food. The transition changed when the frame showed Andrie Jhony sitting at the dinner table while eating the cooked dishes.

Andrie Jhony's voice became the narrator of the advertisement "Find out more in Kecap ABC's Real Husband Academy" with a tablet that showed Kecap ABC advertisements with a pair of husband and wife who were previously found in the first advertisement, and a description of the website page www. akademisuamisejati.com.

Overall this advertisement shows that men can feel sadness and seem lost but not dragging on. The masculine identity that sticks in men is remediated and reconstructed, and it reflects an identity that does not expect men to be mentally strong, but to be able to evaluate themselves for mistakes that have been made and to go through various expressions of sadness.

\section{Conclusion}

The relations between modalities in Kecap ABC's advertisements negotiate the existing concept of masculinity and state-formalized ideology of gender roles, that is the role of man is in the public sector while woman is in the domestic sector. In the first advertisement the awareness of role taking in the domestic sector by the man was influenced by the man's dialogue with a child. Whereas in the second advertisement male's domestic role-taking came from regret following his divorce. These two advertisements indicates a patriarchal counter-hegemony. Even so there is a discursive trace in which the patriarchal ideology settles that idealizes the role of men in the household as a 'helper' in cooking activities, which means that the person who is truly responsible for the activity is still the wife or a woman.

What is shown by these two advertisements is an attempt to counter the ideology that gains prevalence in the New Order era and its imaginations about the ideal role of women. Subijakto Priosoedarsono (1998) posits that advertisements in the New Order era had a tendency to describe women as servants of husbands in the family. Advertisements that represented the family during the New Order period were influenced by Javanese values of idealized woman. Noviani (2011) explained that although the 
repressive New Order regime had fallen, its ideology and imagination about the family continues to prevail in popular cultural shows, especially advertisements. These advertisements of Kecap $A B C$ are parts of an effort to counter the imagination of women who was solidified and worked discursively during the New Order period.

Both of these advertisements position men, which are represented by husbands and ex-husbands, as interactional controllers. In the first advertisement, for example, the figure that allows a change in the role of cooking is a man. If the man did not initiate it as a result of a discussion with his child, the change is assumed not to occur. Women are only represented as passive figures who accepts her role as a career-woman while also taking up domestic work, such as cooking, in her daily routine. Of course other alternative narratives are needed, which could show how women can also be active in the domestic and public division of labor in various advertisements or other popular cultural products. The second advertisement indirectly gives identity or ethos to the wife figure who only appears in the form of photos. The advertisement implies that the divorce decision was taken by the ex-wife because the husband did not take part in domestic work, and is too fixated on work from day to night. In this case men are represented as the recipients of consequences for their own behavior.

Remediation of gender dichotomy through alternative narratives on Kecap ABC's advertisements is done by combining many aspects in one content, which are audio, visual, and website. The advertisements were also available on Youtube and the television at the same time. The aspects of mediation-audio, visual, website-in remediation, which is called hypermediation, are intended for Indonesian viewers to get a more unified media experience in which they will be able to get experience the advertisement from various platforms. These variety of platforms also teased the eyes, ears, and maybe the mouth of the audiences so the remediation of reality feels more realistic. Even further, the remediation processes in these two advertisemens show that gender does not define what kind of roles in the family. Instead, the advertisements take an effort to counter the hegemonic patriarchal discourse that usually appears in Indonesian advertisements in the television that is related to family 
and the roles of family members or even in real life itself.

\section{References}

Arya, N., Cangara, H. And Ude, A. A. (2013). Komodifikasi kemiskinan dalam televisi Indonesia: Studi komparatif antara program "Jika Aku Menjadi" di Trans TV dengan program "Bedah Rumah" di RCTI. Jurnal Komunikasi KAREBA, 2(2), 175-185.

Black, I. R., and Morton, P. (2015). Appealing to men and women using sexual appeals in advertising: In the battle of the sexes, is a truce possible?. Journal of Marketing Communication, 23(4), 331-350.

Burton, G. (2002). More than meets the eye: An introduction to media studies. London, United Kingdom: Oxford University Press.

Bolter, J. D. and Grusin, R. (1999). Remediation: Understanding new media. Cambridge, MA: MIT Press.

Brandt, A. M. (1995). The cigarette, risk, and American culture. Rothstein, W. G. (Ed.) Readings in American Health Care (pp. 138-150). Madison, WI: University of Wisconsin Press.

Eisend, M., Plagemann, J. and Sollwedel, J. (2014). Gender roles and humor in advertising: The occurence of stereotyping in humorous and nonhumorous advertising and its consequences for advertising effectiveness. Journal of Advertising, 43(3), 256-273.

Fairclough, N. (1992). Discourse and social change. Oxford, United Kingdom: Polity Press.

Fathinah, E., Aquarini, P. and Adji, M. (2017). Maskulinitas baru dalam iklan kosmetik Korea: Etude House dan Tonymoly. Jurnal Patanjala, 9(2), 213-228.

Fernandez, P.W. (2011). Komodifikasi perempuan dalam iklan televisi. Jurnal IImu Komunikasi, 8(1), 60-80.

Fitriana, R. (2014). Perempuan dan sensualitas: Bentuk komodifikasi tubuh perempuan melalui body images yang dikonstruksikan di dalam Iklan Axe. Commonline, 3(2), 16-27.

Fowler, K., and Thomas, V. (2015). A content analysis of male roles in television advertising: Do traditional roles still hold?. Journal of Marketing Communications, 21(5), 356-371.

Framanik, N. A. (2012). Komodifikasi ikon perempuan dalam tayangan iklan televisi. Jurnal Riset Komunikasi, 3(6), 252-261. 
Grau, S. L., and Zotos, Y. C. (2016). Gender stereotypes in advertising: A review of current research. International Journal of Advertising, 35(5), 761-770.

Harrison, C. (2008). Real men do wear mascara: Advertising discourse and masculine identity. Critical Discourse Studies, 5(1), 55-74.

Hatzithomas, L., Boutsouki, C., and Ziamou, P. (2016). A longitudinal analysis of the changing roles of gender in advertising: A content analysis of Super Bowl commercials. International Journal of Advertising, 35(5), 888-906.

Heinz ABC (2018a). Suami sejati mau masak, terima kasih Kecap $A B C$ [Youtube]. Jakarta, Indonesia.

Heinz ABC (2018b). Kecap ABC bantu suami jadi pasangan yang setara [Youtube]. Jakarta, Indonesia.

Heinz ABC (2019). History. Heinz ABC. Retrieved from www.heinzabc.co.id/ history/en

Hermawan, H., Hamzah, R. E. (2017).

Objektifikasi perempuan dalam iklan televisi: Analisis lintas dudaya terhadap iklan parfum Axe yang tayang di televisi Indonesia dan Amerika Serikat. Jurnal Kajian Media, 1(2), 166-176.

Kim, K., \& Lowry, D. T. (2005). Television commercials as a lagging social indicator: Gender role stereotypes in Korean television advertising. Sex Roles: A Journal of Research, 53(11/12), 901-910.

Kimmel, A. J. and Tissier-Desbordes, E. (1999). Males, masculinity, and consumption: An exploratory investigation. European Advances in Consumer Research, Vol. 4, 243-51.

Kitley, P. (2000). Television, nation, and culture in Indonesia. Athens, $\mathrm{OH}$ : Ohio University Center for International Studies.

Kress, G. and van Leeuwen, T. (2001). Multimodal discourse: The modes and media of contemporary communication. London, United Kingdom: Oxford University Press.

Kress, G. (2009). Multimodality: A social semiotic approach to contemporary communication. New York, NY: Routledge.

Marriage Law 1974. (1974) Retrieved from http://repo.unand. ac.id/2798/1/1974_UU - 1 TAHUN-1974_PERKAWINAN.pdf

Mulder, N. (2001). Mistisisme Jawa : Ideologi di Indonesia. Yogyakarta, Indonesia: LKIS

Noor, F. and Wahyuningratna, R. N. (2017). Representasi sensualitas perempuan dalam iklan New Era 
Boots di televisi: Kajian semiotika Roland Barthes. Ikraith-Humanoria, 1(2), 1-9.

Noviani, R. (2011). Ambiguity of images:

Visualizing ethnic/racial differences in Indonesian TV advertisements during the New Order and the Post-New Order era. Asien: Deutsche Zeitschrift Für Politik, Wirtschaft Und Kultur, 118(1), 29-49.

Perdana, D. D. (2017). Komodifikasi dalam tayangan televisi: Kajian terhadap program Indonesian Idol 2014. Jurnal Professional FIS UNIVED, 4(1), 12-21.

Prameswari, N. S. (2014). Di balik maskulinitas iklan rokok: Kritik terhadap iklan rokok A Mild Media Outdoor versi Berani Takut. Jurnal Imaji, 12(2), 39-54.

Pratiwi, H. A. and Wiyanti, E. (2017).

Representasi kesetaraan gender pada iklan: Tinjauan semiotika citra laki-Laki dalam keluarga pada iklan televisi. Jurnal Desain, 4(3), 212-230.

Prior, P., Hengst, J., Roozen, K. and Shipka, J. (2007). 'I'll be the sun': From reported speech to semiotic remediation practices. Text $\&$ Talk: An Interdisciplinary Journal of Language, Discourse \& Communication Studies, 26(6), 733-766.
Priosoedarsono, S. (1998). Peranan wanita dalam periklanan. Ibrahim, I. S. and Suranto, H (Eds.), Wanita dan media: Konstruksi ideologi gender dalam ruang publik Orde Baru (pp. 305309). Bandung, Indonesia: PT Remaja Rosdakarya.

Silverstone, R. (1999). Why study the media?. London, United Kingdom: SAGE Publications.

Siswati, Endah. (2014). Representasi domestikasi perempuan dalam iklan. Jurnal IImu Komunikasi, 11(2), 179194.

Suryakusuma, J. (2011). The social construction of womanhood in New Order Indonesia. Depok, Indonesia: Komunitas Bambu.

Tanjung, S. (2012). Pemaknaan maskulinitas pada majalah Cosmopolitan Indonesia. Jurnal Komunikasi, 6(2), 91-104.

Verhellen, Y., Dens, N., and de Pelsmacker, P. (2016). A longitudinal content analysis of gender role portrayal in Belgian television advertising. Journal of Marketing Communications, 22(2), 170-188.

Wafiroh, H. (2017). Interaksi sosial wanita pengrajin tenun ikat Troso dalam kegiatan Pemberdayaan 
dan Kesejahteraan Keluarga (PKK). Winata, I N.. (2012). Hegemoni ljtimaiya: Journal of Social Science maskulinitas dalam iklan minuman Teaching, 1(1), 1-17. berenergi: Analisis semiotika TVC

Wieringa, S. E. (1999). Penghancuran Ekstra Joss dan Kuku Bima Ener-G. gerakan perempuan di Indonesia. Jurnal IImiah Komunikasi MAKNA, Jakarta, Indonesia: Kalyanamitra. 3(1), 42-29. 